Article

\title{
The Effect of Hydrogen Sulfide on Different Parameters of Human Plasma in the Presence or Absence of Exogenous Reactive Oxygen Species
}

\author{
Beata Olas *, Paulina Brodek and Bogdan Kontek \\ Department of General Biochemistry, Faculty of Biology and Environmental Protection, University of Lodz, \\ Pomorska 141/3, 90-236 Lodz, Poland; paulina.brodek@gmail.com (P.B.); bogdan.kontek@biol.uni.lodz.pl (B.K.) \\ * Correspondence: beata.olas@biol.uni.lodz.pl; Tel./Fax: +48-42-635-4484
}

Received: 12 November 2019; Accepted: 29 November 2019; Published: 3 December 2019

\begin{abstract}
The main aim of the study is to examine the effect of sodium hydrosulfide (NaHS), an $\mathrm{H}_{2} \mathrm{~S}$ donor, on the oxidative stress in human plasma in vitro. It also examined the effects of very high concentrations of exogenous hydrogen sulfide on the hemostatic parameters (coagulation and fibrinolytic activity) of human plasma. Plasma was incubated for 5-30 min with different concentrations of NaHS from 0.01 to $10 \mathrm{mM}$. Following this, lipid peroxidation was measured as a thiobarbituric acid reactive substance (TBARS) concentration and the oxidation of amino acid residues in proteins was measured by determining the amounts of thiol groups and carbonyl groups. Hydrogen peroxide $\left(\mathrm{H}_{2} \mathrm{O}_{2}\right)$ and the hydroxyl radical generating oxidation system $\left(\mathrm{Fe} / \mathrm{H}_{2} \mathrm{O}_{2}\right)$ were used as oxidative stress inducers. Hemostatic factors, such as the maximum velocity of clot formation, fibrin lysis half-time, the activated partial thromboplastin time (APTT), thrombin time (TT), and international normalized ratio (INR), were estimated. Changes in lipid peroxidation, carbonyl group formation, and thiol group oxidation were detected at high concentrations of $\mathrm{H}_{2} \mathrm{~S}(0.1-10 \mathrm{mM})$, and these results indicate that $\mathrm{NaHS}$ (as the precursor of $\mathrm{H}_{2} \mathrm{~S}$ ) may have pro-oxidative effects in human plasma in vitro. Moreover, considering the data presented in this study, we suggest that the oxidative stress stimulated by NaHS (at high concentrations: $1-10 \mathrm{mM}$ ) is not involved in changes of the hemostatic activity of plasma.
\end{abstract}

Keywords: hydrogen sulfide; plasma; oxidative stress; pro-oxidant; hemostasis

\section{Introduction}

Hydrogen sulfide $\left(\mathrm{H}_{2} \mathrm{~S}\right)$ is a well-known toxic gas synthesized from the amino acids L- and D-cysteine (Cys) and L-homocysteine (L-Hcy). Its biosynthesis involves four enzymes: cystathionine- $\beta$ synthase (CBS), mercaptopyruvate sulfurtransferase (3-MST), cystathionine- $\gamma$-lyase (CSE), and cysteine aminotransferase [1]. $\mathrm{H}_{2} \mathrm{~S}$ is known to play an important role in various biological systems, including the cardiovascular system [2-8], and our own previous research has shown that the administration of 0.01 and $0.1 \mathrm{mM} \mathrm{H}_{2} \mathrm{~S}$ may reduce the plasma lipid peroxidation induced by various forms of homocysteine [9], which indicates the existence of a relationship between the presence of homocysteine and cardiovascular diseases.

Zaicho et al. [10] classified modulators of $\mathrm{H}_{2} \mathrm{~S}$ metabolism into three groups: (1) agents that reduce the amount of hydrogen sulfide in tissues (specific and nonspecific inhibitors of $\mathrm{H}_{2} \mathrm{~S}$ synthesis), (2) agents with an uncertain impact (some medicines), and (3) agents that increase the amount of hydrogen sulfide (inorganic and organic $\mathrm{H}_{2} \mathrm{~S}$ donors). Sodium hydrosulfide (NaHS) and sodium sulfide $\left(\mathrm{Na}_{2} \mathrm{~S}\right)$ were the first $\mathrm{H}_{2} \mathrm{~S}$ donors to be studied in the cardiovascular system [11]. $\mathrm{Na}_{2} \mathrm{~S}$ is currently under evaluation in phase I and II trials as a therapeutic agent. 
As the influence of $\mathrm{H}_{2} \mathrm{~S}$ on oxidative stress remains unknown, and is sometimes controversial, the aim of our study was to determine the effects of sodium hydrosulfide on oxidative stress in human plasma when administered at concentrations of 0.01 to $10 \mathrm{mM}$ in vitro. The study also tested the activity of $\mathrm{H}_{2} \mathrm{~S}$ against the effect of two oxidants, namely hydrogen peroxide $\left(\mathrm{H}_{2} \mathrm{O}_{2}\right)$ and $\mathrm{Fe} / \mathrm{H}_{2} \mathrm{O}_{2}$ (a hydroxyl radical donor), on plasma lipids and proteins. The present study used plasma because it is a very important element of hemostasis. Reactive oxygen species (ROS) may induce changes in both the structure and the function of plasma lipids and proteins, which are important hemostatic components and initial targets for ROS. Oxidative modifications of these components have been reported in various conditions, including cardiovascular disorders. The models used in this experiment were similar to the reactions that take place in plasma under oxidative stress conditions. Oxidative stress was measured by examining the concentrations of well-known biomarkers: thiobarbituric acid reactive substance (TBARS), which is a marker of lipid peroxidation; and the concentrations of carbonyl and thiol groups, which are markers of oxidative damage in proteins.

The toxic and therapeutic effects of $\mathrm{H}_{2} \mathrm{~S}$ depend on its concentration. Endogenous concentrations of hydrogen sulfide in human plasma are described within the range 34-65 $\mu \mathrm{M}$ [12]. In the present study, NaHS was administered at concentrations ranging from 0.01 to $10 \mathrm{mM}$, as these low and high values have also been used in previous studies; Zagli et al. [13] observed that $10 \mathrm{mM}$ NaHS induced the total inhibition of blood platelet aggregation, a very important process in hemostasis, and this inhibition was found to be concentration dependent. Moreover, when fibrinogen was treated with NaHS, even at the highest concentrations of NaHS $(1,5$, and $10 \mathrm{mM})$, it was found to have an inhibitory effect on blood platelet adhesion to modified fibrinogen, a very important hemostatic protein involved in the coagulation process and platelet aggregation [14]. Our earlier results indicate that exogenous $\mathrm{H}_{2} \mathrm{~S}$ has anticoagulant properties when administered at physiological concentrations $(0.01-100 \mu \mathrm{M})$ [15]. As the mechanism(s) behind the relationship between the action of hydrogen sulfide at very high concentrations and hemostasis are still unknown, a secondary aim of our study was to examine the effects of 1,5, and $10 \mathrm{mM}$ sodium hydrosulfide on the coagulation and fibrinolytic activities of human plasma by determining the maximum velocity of polymerization and the half-life of fibrin lysis. We also examined the amidolytic activity of plasmin in human plasma, and its influence on other hemostatic parameters: the activated partial thromboplastin time (APTT), thrombin time (TT), and international normalized ratio (INR) of human plasma in vitro.

\section{Materials and Methods}

Sodium hydrosulfide, which is known to be a reliable $\mathrm{H}_{2} \mathrm{~S}$ donor [16,17], thiobarbituric acid (TBA), 5,5'-dithio-bis-(2-nitrobenzoic acid) (DTNB), and $\mathrm{H}_{2} \mathrm{O}_{2}$ were purchased from Sigma Chemical Co. (Steinheim, Germany). Reagents (for the measurement of hemostasis) were obtained from Diagon Ltd. (Budapest, Hungary) and Boehringer Ingelheim (Ingelheim, Germany). All other chemicals were reagent-grade products purchased from POCh (Gliwice, Poland).

\subsection{Exposure of Human Plasma to NaHS}

Human plasma was obtained from medication-free, regular donors at the blood bank (Lodz, Poland). Plasma was exposed to: (1) NaHS at a final concentration between 0.01 and $10 \mathrm{mM}$, (2) NaHS at a final concentration between 0.01 and $10 \mathrm{mM}$ plus $2 \mathrm{mM} \mathrm{H}_{2} \mathrm{O}_{2}$, and (3) $\mathrm{NaHS}$ at a final concentration between 0.01 and $10 \mathrm{mM}$ plus $4.7 \mathrm{mM} \mathrm{H}_{2} \mathrm{O}_{2} / 3.8 \mathrm{mM} \mathrm{Fe}_{2} \mathrm{SO}_{4} / 2.5 \mathrm{mM}$ EDTA. Samples were incubated for 5,15 , and $30 \mathrm{~min}$ at $37^{\circ} \mathrm{C}$ (in air-tight tubes).

\subsection{Lipid Peroxidation Measurement}

Plasma lipid peroxidation was quantified by measuring the concentration of TBARS. The TBARS concentration was calculated using the molar extinction coefficient $\left(\varepsilon=156,000 \mathrm{M}^{-1} \mathrm{~cm}^{-1}\right)$. More details are described in Wachowicz [18]. 


\subsection{Carbonyl Group Measurement}

Detection of the carbonyl groups in plasma proteins was carried out according to Dalle-Donne et al. [19]. 2,4-Dintrophenylhydrazine (DNPH) was used for detecting the carbonyl groups. The content of the colored compound was measured spectrophotometrically at $375 \mathrm{~nm}$ (using a Helios Alpha UV/Vis Spectrophotometer (Unicam, (Cambridge, UK)). The carbonyl group concentration was calculated based on the molar extinction coefficient $\left(\varepsilon=22,000 \mathrm{M}^{-1} \mathrm{~cm}^{-1}\right)$.

\subsection{Thiol Group Measurement}

The level of the thiol group in plasma proteins was measured spectrophotometrically using a Helios Alpha UV/Vis Spectrophotometer (Unicam) with Ellman's reagent, i.e., 5,5'-dithiobis-(2-nitrobenzoic) acid (DTNB). The thiol group concentration was calculated using the molar extinction coefficient $\left(\varepsilon=13,600 \mathrm{M}^{-1} \mathrm{~cm}^{-1}\right)[20,21]$.

\subsection{The Measurement of Hemostasis Parameters: APTT, TT, INR, Fibrin Polymerization, and Lysis in Plasma}

The coagulation times (APTT, TT, and INR) were determined coagulometrically using a K-3002 Optic Coagulation Analyser (Kselmed, Grudziadz, Poland) [22]. Fibrin polymerization and lysis were carried out according to Malinowska et al. [23]. The maximal velocity ( $\mathrm{V}_{\max }, \mathrm{mOD} / \mathrm{min}$ ) and maximal absorbance $\left(A_{\max }\right)$ were recorded for each absorbance curve. The half-lysis time was defined as the time needed for the elastic modulus to decline to $50 \%$ of its peak value $\left(\frac{1}{2} A_{\max }\right)$ [23].

\subsection{Data Analysis}

All the values in this study are expressed as means \pm SE. The results were analyzed using ANOVA and the Bonferroni post hoc test. In order to eliminate uncertain data, the Q-Dixon test was performed. The level of statistical significance for all tests was taken to be $p<0.05$.

\subsection{Statements about Research Involving Human Participants and/or Animals}

The protocol of the experiment was approved by the Committee for Research on Human Subjects of the University of Lodz: numbers KBBN-UŁ/I/5/2011 and KBBN-UŁ/II/18/2011.

\section{Results}

NaHS that was added to human plasma in vitro at concentrations of $0.1-10 \mathrm{mM}$ induced lipid peroxidation (measured using the TBARS level) after 5, 15, and $30 \mathrm{~min}$ of incubation (Table 1). The TBARS level increased by about $45 \%$ in the presence of $1 \mathrm{mM}$ NaHS after a short incubation time ( $5 \mathrm{~min}$ ) compared with the control values (Table 1). However, although the degree of lipid peroxidation of human plasma treated with $0.01 \mathrm{mM}$ NaHS for 5 min was lower than that observed for the controls, this effect was not statistically significant (Table 1). On the other hand, the lipid peroxidation of plasma treated with $0.01 \mathrm{mM}$ for 15 and $30 \mathrm{~min}$ was higher than that observed for the control, but for $30 \mathrm{~min}$ of incubation, this effect was statistically significant (Table 1). Lipid peroxidation was also enhanced when NaHS was applied at 1-10 mM in human plasma treated with $\mathrm{H}_{2} \mathrm{O}_{2}$ or $\mathrm{Fe} / \mathrm{H}_{2} \mathrm{O}_{2}$ (Figure 1). In addition, the lipid peroxidation induced by $\mathrm{Fe} / \mathrm{H}_{2} \mathrm{O}_{2}$ was not influenced by $\mathrm{NaHS}$ at lower concentrations $(0.01$ and $0.1 \mathrm{mM}$ ) (Figure 1). 


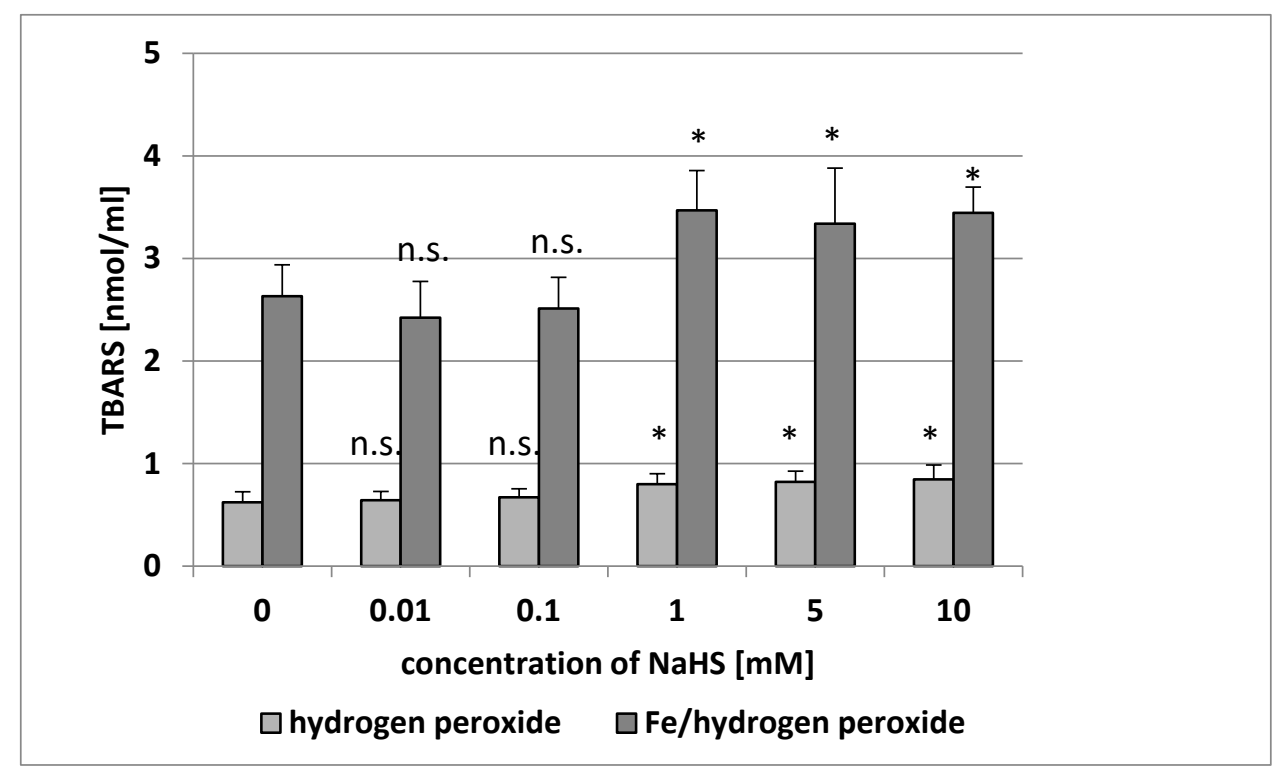

Figure 1. The effect of NaHS (0.01-10 $\mathrm{mM}$, incubation time: $5 \mathrm{~min}$ ) on plasma lipid peroxidation induced by $\mathrm{H}_{2} \mathrm{O}_{2}$ and by $\mathrm{Fe} / \mathrm{H}_{2} \mathrm{O}_{2}$. Data represents the means $\pm \mathrm{SE}$ of five experiments. *: $p<0.05$ versus the control (plasma with $\mathrm{H}_{2} \mathrm{O}_{2}$ or $\mathrm{Fe} / \mathrm{H}_{2} \mathrm{O}_{2}$ ), n.s.: $p>0.05$ versus control (plasma with $\mathrm{H}_{2} \mathrm{O}_{2}$ or $\mathrm{Fe} / \mathrm{H}_{2} \mathrm{O}_{2}$ ). TBARS: thiobarbituric acid reactive substance.

Table 1. The effect of NaHS (0.01-10 mM, incubation time: $5 \mathrm{~min}, 15 \mathrm{~min}$, and $30 \mathrm{~min}$ ) on plasma lipid peroxidation. Data represents means $\pm \mathrm{SE}$ of five experiments.

\begin{tabular}{|c|c|c|c|c|}
\hline \multirow{2}{*}{$\begin{array}{l}\text { Concentration of } \\
\text { NaHS (mM) }\end{array}$} & \multicolumn{4}{|c|}{ TBARS (nmol/mL) } \\
\hline & 0 & 5 & 15 & 30 \\
\hline 0 & $0.522 \pm 0.099$ & $0.501 \pm 0.070$ & $0.488 \pm 0.085$ & $0.541 \pm 0.059$ \\
\hline 0.01 & $\begin{array}{c}0.511 \pm 0.077 \\
\text { (n.s. vs. control) }\end{array}$ & $\begin{array}{c}0.489 \pm 0.067 \\
\text { (n.s. vs. control) }\end{array}$ & $\begin{array}{c}0.588 \pm 0.059 \\
\text { (n.s. vs. control) }\end{array}$ & $\begin{array}{c}0.579 \pm 0.059 \\
(p<0.05 \text { vs. control })\end{array}$ \\
\hline 1 & $\begin{array}{c}0.532 \pm 0.078 \\
\text { (n.s. vs. control) }\end{array}$ & $\begin{array}{c}0.800 \pm 0.099 \\
(p<0.001 \text { vs. control })\end{array}$ & $\begin{array}{c}0.817 \pm 0.089 \\
(p<0.001 \text { vs. control })\end{array}$ & $\begin{array}{c}0.680 \pm 0.087 \\
(p<0.02 \text { vs. control })\end{array}$ \\
\hline 5 & $\begin{array}{c}0.552 \pm 0.110 \\
\text { (n.s. vs. control) }\end{array}$ & $\begin{array}{c}0.613 \pm 0.111 \\
(p<0.05 \text { vs. control })\end{array}$ & $\begin{array}{c}0.635 \pm 0.080 \\
(p<0.05 \text { vs. control })\end{array}$ & $\begin{array}{c}0.622 \pm 0.116 \\
(p<0.05 \text { vs. control })\end{array}$ \\
\hline
\end{tabular}

Our results demonstrate that the level of carbonyl groups was low in human plasma: $1.243 \pm$ $0.269 \mathrm{nmol} / \mathrm{mg}$ of plasma proteins. The addition of NaHS $(0.1-10 \mathrm{mM})$ to plasma induced oxidative alterations in proteins as measured by the number of $\mathrm{CO}$ groups (Figure 2). NaHS significantly stimulated carbonyl group formation in plasma proteins treated with $\mathrm{H}_{2} \mathrm{O}_{2}$ by about $10 \%$ when administered at $1 \mathrm{mM}$ (Figure 2). NaHS (at higher tested concentrations: 5 and $10 \mathrm{mM}$ ) also stimulated carbonylation of plasma proteins treated with $\mathrm{H}_{2} \mathrm{O}_{2}$ (Figure 2). On the other hand, none of the tested concentrations of NaHS (0.01-10 $\mathrm{mM})$ was found to change the carbonylation of plasma proteins induced by $\mathrm{Fe} / \mathrm{H}_{2} \mathrm{O}_{2}$ (Figure 2). 


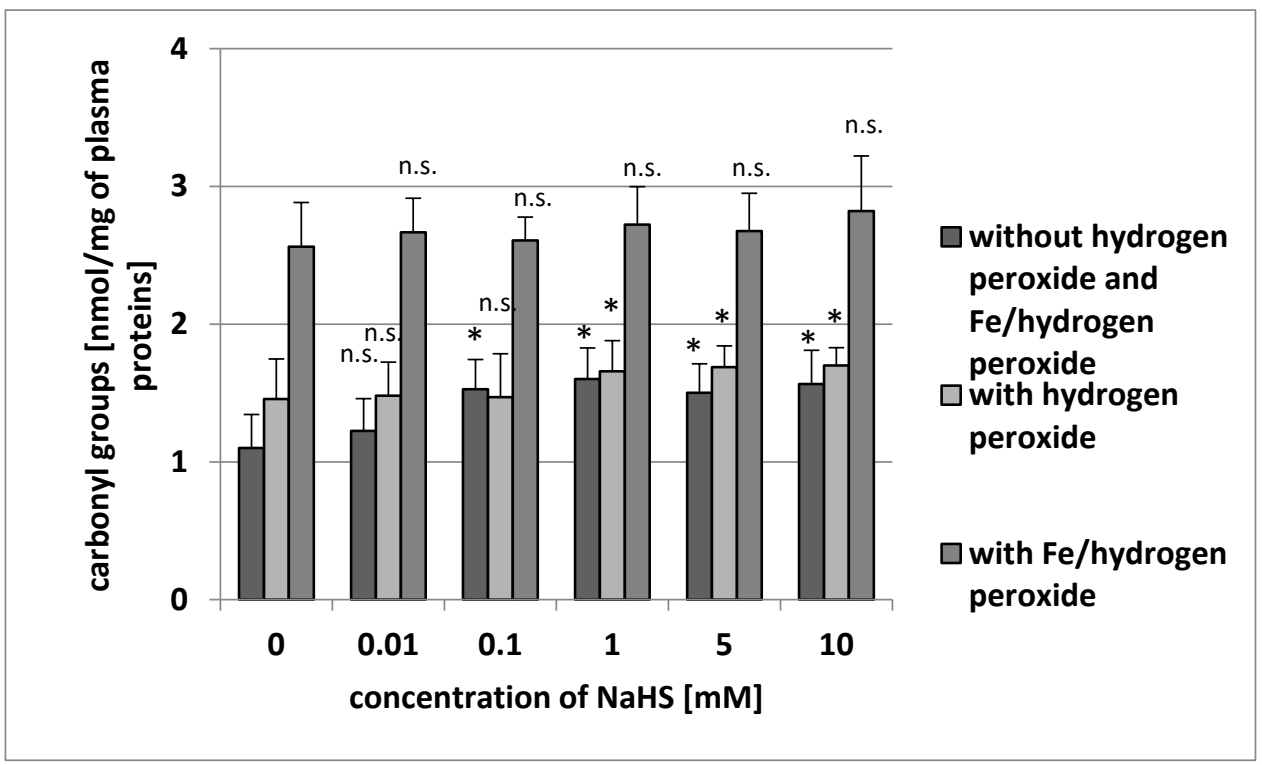

Figure 2. The effect of NaHS (0.01-10 $\mathrm{mM}$, incubation time: $5 \mathrm{~min}$ ) on carbonyl group formation (plasma protein oxidation) without $\mathrm{H}_{2} \mathrm{O}_{2}$ and $\mathrm{Fe} / \mathrm{H}_{2} \mathrm{O}_{2}$, and carbonyl group formation (plasma protein oxidation) induced by $\mathrm{H}_{2} \mathrm{O}_{2}$ and by $\mathrm{Fe} / \mathrm{H}_{2} \mathrm{O}_{2}$. Data represents the means $\pm \mathrm{SE}$ of five experiments. *: $p<0.05$ versus control, n.s.: $p>0.05$ versus control.

Although NaHS did not change the level of thiol groups in plasma proteins when administered without the addition of $\mathrm{H}_{2} \mathrm{O}_{2}$ or $\mathrm{Fe} / \mathrm{H}_{2} \mathrm{O}_{2}(p>0.05)$, a significant decrease was observed in the level of thiol groups in plasma proteins compared with the controls $\left(\mathrm{H}_{2} \mathrm{O}_{2}\right.$ or $\left.\mathrm{Fe} / \mathrm{H}_{2} \mathrm{O}_{2}\right)$ when plasma was incubated with high concentrations of NaHS (1-10 mM) and with $\mathrm{H}_{2} \mathrm{O}_{2}$ or $\mathrm{Fe} / \mathrm{H}_{2} \mathrm{O}_{2}$ (Figure 3).

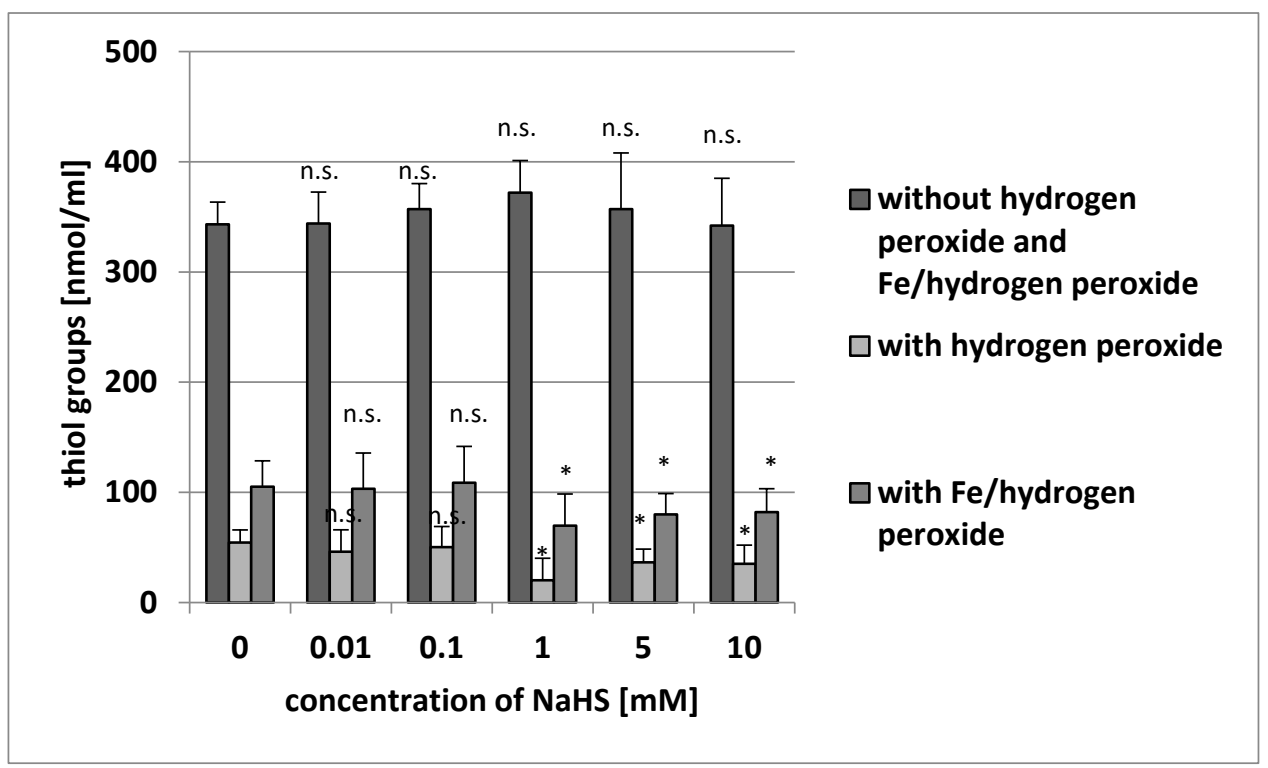

Figure 3. The effect of NaHS $(0.01-10 \mathrm{mM}$, incubation time: $5 \mathrm{~min}$ ) on the level of thiol groups of plasma proteins (plasma protein oxidation) without $\mathrm{H}_{2} \mathrm{O}_{2}$ and $\mathrm{Fe} / \mathrm{H}_{2} \mathrm{O}_{2}$, and the oxidation of protein thiols induced by $\mathrm{H}_{2} \mathrm{O}_{2}$ and by $\mathrm{Fe} / \mathrm{H}_{2} \mathrm{O}_{2}$. Data represents the means $\pm \mathrm{SE}$ of five experiments. * $p<0.05$ versus control, n.s.: $p>0.05$ versus control.

Incubation (5 min) with NaHS (at tested concentrations: 1, 5, and $10 \mathrm{mM}$ ) did not induce changes in the coagulation properties of plasma (Table 2). Incubation of human plasma ( $5 \mathrm{~min}$ ) with NaHS $(1,5$, and $10 \mathrm{mM})$ did not change APTT, TT, INR (data are not presented), the maximal velocity of 
fibrin polymerization, or the fibrin lysis in plasma (Table 2). The same process was observed at longer incubation times of 15 and $30 \mathrm{~min}$ (data are not presented).

Table 2. The effect of NaHS on the biological activity of plasma (selected elements of hemostasis). $\mathrm{NaHS}$ was preincubated for $5 \mathrm{~min}$ at $37^{\circ} \mathrm{C}$ with plasma at final concentrations of $1-10 \mathrm{mM}$.

\begin{tabular}{|c|c|c|}
\hline \multirow{2}{*}{ Concentration of $\mathrm{NaHS}(\mathrm{mM})$} & \multicolumn{2}{|c|}{ Hemostatic Parameters } \\
\hline & Fibrin Polymerization $\mathrm{V}_{\max }$ (\% Control) & Fibrin Lysis Time of $50 \%$ Lysis (\% Control) \\
\hline 0 (control) & 100 & 100 \\
\hline $1 \mathrm{mM}$ & $98.8 \pm 12.5$ (n.s.) & $104.9 \pm 10.3$ (n.s.) \\
\hline $5 \mathrm{mM}$ & $99.2 \pm 15.5$ (n.s.) & $109.9 \pm 13.7$ (n.s.) \\
\hline \multirow[t]{2}{*}{$10 \mathrm{mM}$} & $99.7 \pm 14.8$ (n.s.) & $115.8 \pm 19.2$ (n.s.) \\
\hline & \multicolumn{2}{|c|}{ Plasmin Amidolytic Activity $\mathrm{V}_{\max }(\Delta \mathrm{mOD} / \mathrm{s})$} \\
\hline 0 (control) & \multicolumn{2}{|c|}{$2.057 \pm 0.234$} \\
\hline $1 \mathrm{mM}$ & \multicolumn{2}{|c|}{$2.042 \pm 0.183$ (n.s.) } \\
\hline $10 \mathrm{mM}$ & \multicolumn{2}{|c|}{$1.986 \pm 0.176$ (n.s.) } \\
\hline
\end{tabular}

Data represents the means \pm SE of 3 experiments (plasmin amidolytic activity) or means \pm SE of 10 experiments (for fibrin polymerization and fibrin lysis). n.s.: $p>0.05$.

\section{Discussion}

$\mathrm{H}_{2} \mathrm{~S}$ may play a role in a range of pathophysiological functions by modulating the oxidative stress observed in various disorders [24]. Only a few studies have demonstrated changes in $\mathrm{H}_{2} \mathrm{~S}$ concentrations in human diseases typically associated with oxidative stress, for example, increases have been observed in Down syndrome, septic shock, inflammation of the colon, and diabetes. It is important to note that changes of $\mathrm{H}_{2} \mathrm{~S}$ concentration in patients with chronic obstructive pulmonary disease and in smokers may involve oxidative stress. Wang $[4,25]$ reports that hydrogen sulfide may provide protection against hypertension in diabetic patients. Moreover, Azizi et al. [26] suggest that $\mathrm{H}_{2} \mathrm{~S}$ may act to reduce oxidative stress. However, the actual concentration of $\mathrm{H}_{2} \mathrm{~S}$ in the tested samples was not given; the study simply notes that the level of $\mathrm{H}_{2} \mathrm{~S}$ was elevated based on an observed increase in the expression of enzymes involved in $\mathrm{H}_{2} \mathrm{~S}$ biosynthesis.

As is the case with its therapeutic action, the toxicity of $\mathrm{H}_{2} \mathrm{~S}$ depends on its concentration [27]. Our earlier experiments have demonstrated that in human plasma, the pro-oxidant or antioxidant properties of $\mathrm{H}_{2} \mathrm{~S}$ also depend on its concentration, i.e., $0.01 \mathrm{NaHS}$ reduces lipid peroxidation, $0.1 \mathrm{mM}$ NaHS has no effect on this process, and $1 \mathrm{mM}$ NaHS increases it. Moreover, 0.01 and $0.1 \mathrm{mM} \mathrm{NaHS}$ was found to decrease plasma lipid peroxidation in a hyperhomocysteinemia model [9].

The present study provides more information on the biological activity of $\mathrm{H}_{2} \mathrm{~S}$ in human plasma. Changes in lipid peroxidation, the formation of carbonyl groups, and the oxidation of cysteine residues, demonstrated by the increase of oxidative stress biomarkers, was detected at high concentrations of $\mathrm{H}_{2} \mathrm{~S}$. However, these levels may be toxic and are associated with diseases found to have increases in $\mathrm{H}_{2} \mathrm{~S}$ concentration. Our results are the first to demonstrate the pro-oxidant properties of $\mathrm{H}_{2} \mathrm{~S}$ on a blood plasma oxidative stress model. The study uses a range of biomarkers to measure oxidative stress: TBARS concentration for lipid peroxidation, and protein carbonyl and thiol groups for oxidative damage in proteins. Protein and lipid auto-oxidation was measured following stimulation by two selected reactive oxygen species: $\mathrm{H}_{2} \mathrm{O}_{2}$ and $\mathrm{Fe} / \mathrm{H}_{2} \mathrm{O}_{2}$ (as the donor of $\mathrm{OH} \bullet$ ).

In plasma ( $\mathrm{pH} 7.4$ ) at $37^{\circ} \mathrm{C}, 80 \%$ of the $\mathrm{H}_{2} \mathrm{~S}$ occurs in the form of $\mathrm{HS}^{-}$. Through the transfer of a hydrogen atom or single electron, $\mathrm{HS}^{-}$acts as a strong reducing agent that may "extinguish" free radicals [28]. Recently, experiments have demonstrated that $\mathrm{H}_{2} \mathrm{~S}$ may react with reactive oxygen species and reactive nitrogen species (RNS), i.e., superoxide radical anion $\left(\mathrm{O}_{2}{ }^{-} \bullet\right), \mathrm{H}_{2} \mathrm{O}_{2}$, peroxynitrite $\left(\mathrm{ONOO}^{-}\right)$, or hypochloride. The reaction between $\mathrm{H}_{2} \mathrm{~S}$ and ROS/RNS may protect proteins and lipids from oxidation. Inactive nitrozothiols are formed as a result of a chemical reaction between $\mathrm{H}_{2} \mathrm{~S}$ and nitric oxide $(\mathrm{NO} \bullet)$. Low concentrations of $\mathrm{NaHS}(30-50 \mu \mathrm{M})$ aggravate the protective antioxidative function of glutathione, $\mathrm{N}$-acetylcysteine, catalase, superoxide dismutase, and vitamin $\mathrm{C}$. 
Studies have demonstrated that $\mathrm{H}_{2} \mathrm{~S}$ may decrease the degree of lipid peroxidation, measured as a malondialdehyde (MDA) concentration, and increase the activity of superoxide dismutase in rat hearts subjected to isoproterenol-induced injury [29] and traumatic hemorrhagic shock [30]. Others have found that $\mathrm{H}_{2} \mathrm{~S}$ reduced the ROS level in cardiomyocytes under ischemia/reperfusion [31] and in blood platelets [14]. Kimura and Kimura [32] indicate that $\mathrm{H}_{2} \mathrm{~S}$ protects neurons from oxidative glutamate toxicity (oxytosis) by increasing the production of glutathione, a very important physiological antioxidant. In addition, it inhibits myocardial injury induced by Hcy in rats [33] and reduces the oxidative stress stimulated by Hcy in vascular smooth muscle cells [34]. However, Hamar et al. [35] suggest that $\mathrm{H}_{2} \mathrm{~S}$ is a less effective vascular antioxidant than superoxide dismutase. Morel et al. [14] indicate that $\mathrm{NaHS}$ (at different tested concentrations: 0.00001-10 mM) has antioxidant and antiplatelet properties in human blood platelets in vitro. The authors suggest that the antioxidative properties of $\mathrm{H}_{2} \mathrm{~S}$ may be associated with its antiplatelet activity on human blood platelets. Our present results indicate that NaHS may have had a pro-oxidative effect at higher concentrations $(1,5$, and $10 \mathrm{mM})$, but this did not change the hemostatic properties of plasma. These results may suggest that $\mathrm{H}_{2} \mathrm{~S}$ has different mechanisms of action in blood cells (i.e., platelets) and in plasma.

In the presence of molecular oxygen $\left(\mathrm{O}_{2}\right)$, the auto-oxidation of $\mathrm{H}_{2} \mathrm{~S}$ is known to cause the generation of free radicals $[27,28]$. The present study is the first to describe that $0.1-10 \mathrm{mM} \mathrm{NaHS}$ induced the autoperoxidation of human plasma lipids and carbonylation of plasma proteins. Our findings indicate that 1-10 mM NaHS also intensified the lipid peroxidation induced by $\mathrm{H}_{2} \mathrm{O}_{2}$ and $\mathrm{Fe} / \mathrm{H}_{2} \mathrm{O}_{2}$. Previous studies have reported that 1-10 $\mathrm{mM} \mathrm{NaHS}$ has a pro-oxidative effect on the level of thiol groups in plasma proteins treated with $\mathrm{H}_{2} \mathrm{O}_{2}$ and $\mathrm{Fe} / \mathrm{H}_{2} \mathrm{O}_{2}$. Wedmann et al. [36] note that $\mathrm{NaHS}$ has dramatic actions on protein structure. Our present results indicate that the oxidative protein modifications induced by NaHS may have also stimulated changes in the protein structure. Interestingly, the oxidative stress stimulated by NaHS at high concentrations ranging from 1 to $10 \mathrm{mM}$ was not correlated with changes of hemostasis. The present results are the first to show that high concentrations of $\mathrm{H}_{2} \mathrm{~S}(1-10 \mathrm{mM}$ ) have a different effect on selected elements of hemostasis (coagulation and fibrinolysis) than lower concentrations $(0.01-100 \mu \mathrm{M})$, which have anticoagulant properties [15]. Incubation (5-30 min) with NaHS at tested concentrations (1,5, and $10 \mathrm{mM}$ ) did not induce changes in the coagulation properties of plasma (Table 2). Our findings indicate that the incubation of human plasma for $5 \mathrm{~min}$ with $\mathrm{NaHS}(1,5$, and $10 \mathrm{mM})$ did not change APTT, TT, INR, the maximal velocity of fibrin polymerization, or fibrin lysis in plasma (Table 2).

\section{Conclusions}

The obtained results suggest that $\mathrm{H}_{2} \mathrm{~S}$ at high concentrations, such as $1 \mathrm{mM}$, may have a pro-oxidative effect, and that the oxidative stress induced by ROS may be further enhanced by $\mathrm{H}_{2} \mathrm{~S}$. However, the mechanisms behind this pro-oxidative action remain unknown.

Author Contributions: P.B. did experimental work. B.K. collaborated in analysis of results. B.O. designed the study and performed a version of the manuscript. All authors read and approved the final manuscript.

Funding: This research was funded by Faculty of Biology and Environmental Protection, University of Lodz, grant number 506/1136. The APC was funded by Faculty of Biology and Environmental Protection, University of Lodz.

Conflicts of Interest: The authors declare no conflict of interest.

\section{References}

1. Shibuya, N.; Koike, S.; Tanaka, M.; Ishigami-Yuasa, M.; Kimura, Y.; Ogasawara, Y.; Fukui, K.; Nagahara, N.; Kimura, H. A novel pathway for the production of hydrogen sulfide from D-cysteine in mammalian cells. Nat. Commun. 2013, 4, 1366. [CrossRef]

2. Huges, M.N.; Centelles, M.N.; Moore, K.P. Making and working with hydrogen sulfide: The chemistry and generation of hydrogen sulfide in vitro and its measurement in vivo: A review. Free Radic. Biol. Med. 2009, 47, 1346-1353. [CrossRef] [PubMed] 
3. Tanizawa, K. Production of $\mathrm{H}_{2} \mathrm{~S}$ by 3-mercaptopyruvate sulphurtransferase. J. Biochem. 2011, 149, 357-359. [CrossRef]

4. Wang, R. Physiological implications of hydrogen sulfide-A whiff exploration that lossomed. Physiol. Rev. 2012, 92, 791-896. [CrossRef]

5. Di Masi, A.; Ascenzi, P. $\mathrm{H}_{2}$ S: A “double face” molecule in health and disease. Biofactors 2013, 39, $186-196$. [CrossRef] [PubMed]

6. Hancock, J.T.; Whiteman, M. Hydrogen sulfide and cell signaling: Team player or referee? Plant Physiol. Biochem. 2014, 78, 37-42. [CrossRef] [PubMed]

7. Olas, B. Hydrogen sulfide in hemostasis: Friend or foe? Chem. Biol. Interact. 2014, 217, 49-56. [CrossRef]

8. Xu, S.; Liu, Z.; Liu, P. Targeting hydrogen sulfide as a promising therapeutic strategy for atherosclerosis. Int. J. Cardiol. 2014, 172, 313-317. [CrossRef]

9. Olas, B.; Kontek, B. Hydrogen sulfide decreases the plasma lipid peroxidation induced by homocysteine and its thiolactone. Mol. Cell. Biochem. 2015, 404, 39-43. [CrossRef]

10. Zaicho, N.V.; Melnik, A.V.; Yoltukhivskyy, M.M.; Olhovskiy, A.S.; Palamarchuk, I.V. Hydrogen sulfide: Metabolism, biological and medical role. Ukr. Biochem. J. 2014, 86, 5-25. [CrossRef]

11. Elrod, J.W.; Calvert, J.W.; Morrison, J.; Doeller, J.E.; Kraus, D.W.; Tao, L.; Jiao, X.; Scalia, R.; Kiss, L.; Szabo, C.; et al. Hydrogen sulfide attenuates myocardial ischemia-reperfusion injury by preservation of mitochondrial function. Proc. Natl. Acad. Sci. USA 2007, 104, 15560-15565. [CrossRef]

12. Whiteman, M.; Moore, P.K. Hydrogen sulfide and the vasculature: A novel vasculoprotective entity and regulator of nitric oxide. J. Cell. Mol. Med. 2009, 13, 488-507. [CrossRef] [PubMed]

13. Zagli, G.; Patacchini, R.; Trevisani, M.; Abbate, R.; Cinotti, S.; Gensini, G.F.; Masotti, G.; Geppetti, P. Hydrogen sulfide inhibits human platelet aggregation. Eur. J. Pharmacol. 2007, 559, 65-68. [CrossRef] [PubMed]

14. Morel, A.; Malinowska, J.; Olas, B. Antioxidative properties of hydrogen sulfide may involve in its antiadhesive action on blood platelets. Clin. Biochem. 2012, 18, 1678-1682. [CrossRef]

15. Olas, B.; Kontek, B. The possible role of hydrogen sulfide as a modulator of hemostatic parameters of plasma. Chem. Biol. Interact. 2014, 220, 20-24. [CrossRef]

16. Zhao, W.; Zhang, J.; Lu, Y.; Wang, R. The vasorelaxant effect of $\mathrm{H}(2) \mathrm{S}$ as a novel endogenous gaseous K(ATP) channel opener. EMBO J. 2001, 20, 6008-6016. [CrossRef]

17. Deplanecke, B.; Gaskins, H.R. Hydrogen sulphide induces serum-independent cell cycle entry in nontransformed rat intestinal epithelial cells. FASEB J. 2003, 17, 1310-1312. [CrossRef]

18. Wachowicz, B. Adenine nucleotides in thrombocytes of birds. Cell. Biochem. Funct. 1984, 2, 167-170. [CrossRef]

19. Dalle-Donne, I.; Rossi, R.; Giustarini, D.; Milzani, A.; Colombo, R. Protein carbonyl groups as biomarkers of oxidative stress. Clin. Chim. Acta 2003, 329, 23-38. [CrossRef]

20. Ando, Y.; Steiner, M. Sulphydryl and disulphide groups of platelet membranes. I. Determination of disulphide groups. Biochim. Biophys. Acta Biomembr. 1973, 311, 26-37. [CrossRef]

21. Ando, Y.; Steiner, M. Sulphydryl and disulphide groups of platelet membranes. II. Determination of sulphydryl groups. Biochim. Biophys. Acta Biomembr. 1973, 311, 38-44. [CrossRef]

22. Malinowska, J.; Kołodziejczyk-Czepas, J.; Moniuszko-Szajwaj, B.; Kowalska, I.; Oleszek, W.; Stochmal, A.; Olas, B. Phenolic fractions from Trifolium pallidum and Trifolium scabrum aerial parts in human plasma protect against changes induced by hyperhomocysteinemia. Food Chem. Toxicol. 2012, 50, 4023-4027. [CrossRef] [PubMed]

23. Malinowska, J.; Nowak, P.; Olas, B. Comparison of the effect of the reduced form of homocysteine, its thiolactone and protein homocysteinylation on hemostatic properties of plasma. Thromb. Res. 2011, 127, 214-219. [CrossRef] [PubMed]

24. Olas, B. Medical functions of hydrogen sulfide. Adv. Clin. Chem. 2016, 74, 195-209.

25. Wang, R. Gasotransmitters: Growing ins and joys. Trends Biochem. Sci. 2014, 39, 227-232. [CrossRef]

26. Azizi, F.; Seifi, B.; Kadkhodaee, M.; Ahghari, P. Administration of hydrogen sulfide protects ischemia reperfusion-induced acute kidney injury by reducing the oxidative stress. Ir. J. Med. Sci. 2015, 185, 649-654. [CrossRef]

27. Olas, B. Hydrogen sulfide as a "double-faced" compound: One with pro- and antioxidant effect. Adv. Clin. Chem. 2017, 78, 187-196. 
28. Predmore, B.L.; Lefer, D.J.; Gojon, G. Hydrogen sulfide in biochemistry and medicine. Antioxid. Redox Signal. 2012, 17, 119-140. [CrossRef]

29. Geng, B.; Chang, L.; Pan, C.; Qi, Y.; Zhao, J.; Pang, Y.; Du, J.; Tang, C. Endogenous hydrogen sulfide regulation of myocardial injury induced by isoproterenol. Biochem. Biophys. Res. Commun. 2004, 318, 756-763. [CrossRef]

30. Chai, W.; Wang, Y.; Lin, J.Y.; Sun, X.D.; Yao, L.N.; Yang, Y.H.; Zhao, H.; Jiang, W.; Gao, C.J.; Ding, Q. Exogenous hydrogen sulphide protects against traumatic hemorrhagic shock via attenuation of oxidative stress. J. Surg. Res. 2012, 176, 210-219. [CrossRef]

31. Sun, W.H.; Liu, F.; Chen, Y.; Zhu, Y.C. Hydrogen sulfide decreases the levels of ROS by inhibiting mitochondrial complex IV and increasing SOD activities in cardiomyocytes under ischemia/reperfusion. Biochem. Biophys. Res. Commun. 2012, 421, 164-169. [CrossRef]

32. Kimura, Y.; Kimura, H. Hydrogen sulfide protects neurons from oxidative stress. FASEB J. 2004, 18, $1165-1167$. [CrossRef] [PubMed]

33. Chang, L.; Geng, B.; Yu, F.; Zhao, J.; Jiang, H.; Du, J.; Tang, C. Hydrogen sulfide inhibits myocardial injury induced by homocysteine in rats. Amino Acids 2008, 34, 573-585. [CrossRef]

34. Yan, S.K.; Chang, T.; Wang, H.; Wu, L.; Wang, R.; Meng, Q.H. Effects of hydrogen sulfide on homocysteine-induced oxidative stress in vascular smooth muscle cell. Biochem. Biophys. Res. Commun. 2006, 351, 485-491. [CrossRef]

35. Hamar, J.; Solymar, M.; Tanai, E.; Cseplo, P.; Springo, Z.; Berta, G.; Debreceni, B.; Koller, A. Biassay-comparison of the antioxidant efficacy of hydrogen sulphide and superoxide dismutase in isolated arteries and veins. Acta Physiol. Hung. 2012, 99, 411-419. [CrossRef]

36. Wedmann, R.; Bertlein, S.; Marcinkovic, I.; Bolz, S.; Miljkovic, J.; Munoz, L.; Hermann, M.; Filipovic, M.R. Working with " $\mathrm{H}_{2} \mathrm{~S}^{\prime}$ : Facta and apparent artifacts. Nitric Oxide 2014, 41, 85-96. [CrossRef] [PubMed]

(C) 2019 by the authors. Licensee MDPI, Basel, Switzerland. This article is an open access article distributed under the terms and conditions of the Creative Commons Attribution (CC BY) license (http://creativecommons.org/licenses/by/4.0/). 